\title{
« Irish Culture and Colonial Modernity 1800-2000: The Transformation of Oral Space », David Lloyd
}

\section{Fiona McCann}

\section{(2) OpenEdition \\ 1 Journals}

\section{Édition électronique}

URL : http://journals.openedition.org/etudesirlandaises/3447

DOI : $10.4000 /$ etudesirlandaises.3447

ISSN : 2259-8863

\section{Éditeur}

Presses universitaires de Caen

\section{Édition imprimée}

Date de publication : 30 juillet 2013

ISBN : 978-2-7535-2673-0

ISSN : 0183-973X

\section{Référence électronique}

Fiona McCann, « «Irish Culture and Colonial Modernity 1800-2000: The Transformation of Oral

Space », David Lloyd », Études irlandaises [En ligne], 38-1 | 2013, mis en ligne le 30 juin 2013, consulté le 22 septembre 2020. URL : http://journals.openedition.org/etudesirlandaises/3447 ; DOI : https:// doi.org/10.4000/etudesirlandaises.3447

\section{cc) (†) (ㄱ)}

Études irlandaises est mise à disposition selon les termes de la Licence Creative Commons Attribution - Pas d'Utilisation Commerciale - Partage dans les Mêmes Conditions 4.0 International. 
Decay of Lying, The Critic as Artist, The Truth of Masks, Pen, Pencil and Poison, The Soul of Man under Socialism, The Portrait of MrW.H.), l'esthète disparaît derrière ses écrits où se révèlent tous les aspects de la théorie, toutes les facettes de la persona et, en même temps, la peur que celle-ci ne puisse gagner le combat contre la norme victorienne. Bien sûr, Dorian Gray procède à un savant camouflage de l'homosexualité, mais surtout il peut être lu comme le journal du désarroi face à la fragmentation du moi, tandis que Salome raconte l'histoire d'une persona anéantie par la passion sans limites. La mise en scène brillante du conflit entre stéréotypes et véritables identités dans les comédies apporte sa pierre à l'édifice, couronné enfin, au bout du chemin pénitentiel de la rédemption dans De Profundis et The Ballad of Reading Gaol, par la souffrance, "the means by which we exist ". Un constat prudent clôt l'analyse de l'auteur : "Ultimately one's very self is based on the performance one is permitted to play."

Avec sa bibliographie et ses illustrations bien choisies - un index aurait été bienvenu - ce livre dessine avec précision une trajectoire, et s'en tient avec rigueur à une perspective où ne manquent ni l'érudition ni la fermeté du propos : ce n'est pas un mince mérite.

Claude Fierobe

Université de Reims Champagne-Ardenne

David Lloyd, Irish Culture and Colonial Modernity 1800-2000: The Transformation of Oral Space, Cambridge, Cambridge University Press, 2011, 285 p., ISBN 978-1-1070-0897-7.

In his latest monograph, David Lloyd offers a stimulating analysis of the ways in which, as the subtitle of his work indicates, the oral space in Ireland has been profoundly and radically altered over the last two hundred years or so. Extremely erudite, Lloyd's work retraces the transformation of Irish oral spaces from the clachan to the H-Blocks, via the public house, situating this metamorphosis within the context of capitalist expansion and colonial control and exploring the multifarious examples of Irish disruption of and resistance to attempted restrictions of their circulation in agrarian, labour, leisure and carceral contexts. An impressively well-researched book, as attested to by the number of very informative footnotes, it will appeal to historians, sociologists, anthropologists and literary critics alike, focusing as it does on all these areas, weaving productive links between them. 
The introduction signals the incorporation into this discussion of "the Irish orifice" (1), thus paving the way for later discussions of all bodily senses and indeed other orifices, and makes it clear that Lloyd's aim in this study is to consider the means by which the Irish have, since the Act of Union, been subjected to intense disciplining that can often be traced back to a regulation of the mouth and what enters and leaves it. The following chapters go on to reveal how the "mouth is the privileged corporeal signifier of Irish racial and cultural difference" (3).

In the opening chapter, we are back on familiar Lloyd territory with an indepth discussion of the potato, the famine and the attempts by the British to impose an end to what was perceived as "the threatening presence of Irish differences" and to proffer an image of "their backwardness" (54), notably through attention to their agricultural practices. For instance, a sustained discussion of British attempts to associate the Irish with filth and dung reveals the misunderstanding of the dung-heap as a sign of slovenly lifestyle rather than the sign of industry it actually was. Showing how central Irish labour and goods were to the British economy, contrary to popular belief, Lloyd uncovers the ways in which British attempts to curtail Irish circulation stemmed from a fear of contagion of the British themselves, since "the Irish in their dissoluteness figure as the spectre of the violent dissolution of social ties that capitalism effects and seeks ideologically to rationalize". (44)

The second and third chapters focus respectively on "closing the mouth" (literally, criticising and attempting to end the traditional practices of keening and the wake) and on the public house as a space in which expressions of Irish masculinity could take place. The "ambiguous territory of the mouth" (57) and the organ's association with both excess and lack (of food, drink and words) are investigated, and the act of drinking (rather than sexuality) shown to be the principal means of asserting or performing masculinity at the beginning of the $20^{\text {th }}$ century. Drawing on Fanon, Lloyd highlights the convergence of colonial and nationalist discourses which both sought to eradicate a culture of hard drinking, the latter because it had internalised colonial notions of the Irish as intemperate, and through a reading of Joyce's story "Counterparts", analyses the public house as a site of potential redefinition of Irish masculinity and femininity.

The subsequent two chapters move into the contemporary era and provide extremely thought-provoking reflections on two highly-charged political spaces: the H-Blocks and the notorious British interrogation centre at Castlereagh barracks. Taking issue with the majority of accounts of the IRA prisoners' struggle for Special Category status from the blanket protest in 1976, the subsequent dirty protest, through to the 1981 hunger strike, which, in his view, focus on the mythologisation of the struggle to the detriment of the material context 
and "historical consciousness" (123), Lloyd suggests that the actions of the prisoners are spatially and historically determined and that their agency should be stressed. Replacing this protest within the historical context of the evolution of prison architecture in Britain from the Victorian era onwards, he considers the way in which the British have consistently used the Irish to experiment on different means to perfect the "civilising process" (132) in a way which would never have been possible on the other side of the Irish Sea. Lloyd goes on to explain that the IRA prisoners' subversion of the cell structure in the H-Blocks through Irish classes, debates and singing "transvalued" (145) the prison space and opened up new possibilities for connection, while their use of their mouth and other orifices for sending out and receiving coms displaced the traditional means of communication. Moreover, their smearing of excrement on the walls of their cells completely subverted the prison regulation of the prisoners' bodies and their bodily functions. Lloyd also tackles the much-neglected women's protest in Armagh prison and suggests that while the male prisoners became (corporeally) feminised firstly through their own focus on the holes in their bodies and then through brutal examinations of their orifices, the women prisoners could not read their situation in the same way and this resulted in a reinforcement of their subjection without the potential for subversion or negation available to their male comrades. His discussion of British torture and the tactic of sensory deprivation when interrogating a suspect, as routinely practiced in Castlereagh, is linked to more current debates on the War on Terror, but it also pursues a reflection on strategies of resistance, focusing on one of Bobby Sands' poems and its indebtedness to and "re-vernacularization" (179) of Wilde's “The Ballad of Reading Gaol”.

The final chapter, devoted to Beckett's How It Is, provides a discussion of the political dimension of his "sustained interest in [...] images of the pathological subject" (200) and, unsurprisingly, on the question of voice. It is a fitting conclusion to a book which consistently deals with that which defies rationalisation and which is another excellent contribution by David Lloyd to the field of Irish cultural studies.

Fiona McCann

Université Charles de Gaulle-Lille 3 